\title{
Lotman's semiosphere, Peirce's categories, and cultural forms of life
}

\author{
Floyd Merrell \\ The Department of Foreign Languages and Literatures, \\ Stanley Coulter Hall, Purdue University, \\ West Lafayette, Indiana, IN 47907, USA \\ e-mail: fmerrell@purdue.edu
}

\begin{abstract}
This paper brings Lotman's semiotic space to bear on Peirce's categories of the universe's processes. Particular manifestations of cultural semiotic space within the semiosphere are qualified as inconsistent and/or incomplete, depending upon the cultural context. Inconsistency and incompleteness are of the nature of vagueness and generality respectively, that are themselves qualified in terms of overdetermination and underdetermination, the first being of the nature of the category of Firstness and the second of the nature of Thirdness. The role of Secondness is unfolded by acts of distinguishing the possibilities of Firstness into this and that, here and there, there and then, and all the distinctions that follow. Secondness, then, with respect to cultural semiotic space, gives rise to hegemony, to dominance and subservience, superordination and subordination. Commensurate with this interpretation of Secondness, the realms of overdetermination and underdetermination are labeled homogeny and heterogeny respectively. These theoretical assumptions will then be used as a modeling device providing an interpretation for various key aspects of Latin American cultures.
\end{abstract}

\section{Beginnings}

A few words on Peirce's categories are in order, before we can proceed. Firstness is what it is, without any relationship whatsoever with any other. It is self-contained, self-reflexive, and self-sufficient. Secondness is what it is, insofar as it enters into relationship with something other, interacting with it in the sense of something here and something else there, the first something possibly acting as a sign and the second something acting as the object of the sign. Thirdness is what it is, in the respect that it brings Firstness and Secondness 
together by mediating between them, and hence it brings itself into interaction with them in the same way they are brought into interaction with each other.

We have the interrelations between the categories in Figure 1. Notice how they are "democratic", since each category is interrelated the other two in the same way they are interrelated with each other. Notice that the model is not "triangular", but rather, there are three lines meeting at a point in the form of a "tripod" such that there cannot be merely a binary relation between one category and another, for the relations between any two categories are possible solely by means of interrelations between all three categories. Notice also that the swirling lines illustrating the processual character of these interrelations make up a Borromean knot, well know in mathematical topology. The Borromean knot exercises a move from the twodimensional sheet toward three-dimensionality with the overlapping lines. This is significant, I would respectfully submit. For, the three lines making up the categorical interrelations are not merely twodimensional. They are more properly conceived as a triangle seen from above, that, as a result of the swirling lines of the Borromean knot, oscillate forward and backward. Thus the three-dimensionality of "semiotic space". Speaking of "semiotic space", let us turn to the work of Jurij Lotman for a moment. ${ }^{1}$

Lotman writes that the whole of culture is "immersed in a semiotic space", and subjects within a given culture "can only function by interaction with that space". 2 This combination of signs and semiotic space he calls the "semiosphere". "The semiosphere is the result and the condition for the development of culture; we justify our term by

${ }^{1}$ In a few brief pages I can hardly hope to do justice to the rich thought either of Lotman or of Peirce. Consequently, I limit myself to a few remarks on Peirce's categories and their import to some notions of cultural "logics" I have in mind, and with respect to Lotman I will not enter into a discussion of his rather controversial notion of artistic language as a "secondary modeling system" (Sebeok 1991), nor will I debate the pros and cons of Lotman's "dual models" in the dynamics of culture (Lotman and Uspenskij 1984, Nakhimovsky and Nakhimovsky 1985), the problem of "coding" in semiotic inquiry (Shukman 1977, Merrell 2000a, 2000b), or that of "textuality" (Merrell 2000c). Rather, I will take up what I consider Lotman's chief contribution to the semiotics of culture, his concept of the "semiosphere".

${ }^{2}$ Lotman has defined "semiotic space" in terms of mythology not as a "sign continuum", but as a "totality of separate objects bearing proper names. It is as if space were interrupted by the intervals between objects and thus lacks from our viewpoint such a basic trait as continuity" (Lotman 1977b: 237). It is this discontinuous, even binary, aspect of "semiotic space" that will be under the spotlight in the pages that follow. 
analogy with the biosphere, as Vernadsky defined it, namely the totality and the organic whole of living matter and also the condition for the continuation of life" (Lotman 1990: 124-125). Lotman refers to V. I. Vernadsky, for whom all living organisms are intimately bound to one another and cannot exist as autonomous entities. The biosphere encompasses everything that happens within it with respect to interactions between the living organisms of all communities therein contained. In other words, if we bring Peirce's categories to bear on Vernadsky's biosphere and Lotman's semiosphere, we have the makings of multiple Borromean knots of interrelations that are themselves in perpetual flowing movement in and out of each other while entering into and breaking from triadic interrelations. In other words, we have what we might call a triadically flowing "biosemiosphere". 3

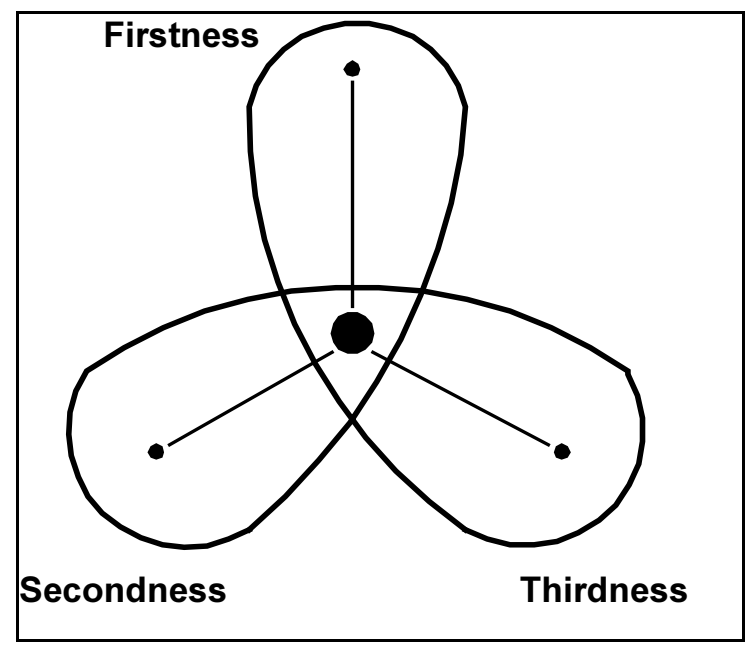

Figure 1. The categories.

${ }^{3}$ Lotman usually keeps the terms in separation, but I include them in one allencompassing term. 


\section{The nature of the biosemiosphere}

We read from Lotman that the biosemiosphere is marked by "heterogeneity". This is because the languages that "fill up the semiotic space are various, and they relate to each other along the spectrum which runs from complete mutual translatability to just as complete mutual untranslatability. Heterogeneity is defined both by the diversity of elements and by their different functions". In this sense, if we imagine a model of a semiotic space where all the languages emerge into existence at one and the same moment, we "still would not have a single coding structure but a set of connected but different systems" (Lotman 1990: 125).

Lotman goes on to write that if we wish to elaborate a model, say, of European Romanticism, we run into problems if we expect to map out homogeneous interrelationships between various expressions of Romanticism from one area to another and from one time period to another. There will be differences not of kind, such as there would be between Romanticism and Neoclassicism, but of degree, of iconic variations or variations of Peirce's Firstness emerging into Secondness, such that there can be no mutually complete translation between one expression of Romanticism and another. This is to say that the biosemiosphere is "asymmetrical". Asymmetry finds expression in the process of internal translation between semiotic space and time from within the biosemiosphere. Translation, Lotman asserts, is "a primary mechanism of consciousness". Expressing an idea in one language and then in another language is to rethink it and in the process to understand it anew and in a more profound way. Since in the majority of cases "the different languages" of the biosemiosphere are "semiotically asymmetrical, i.e. they do not have mutual semantic correspondences", then the whole biosemiosphere "can be regarded as a generator of information" (Lotman 1990: 127).

Allow me, if I may, to put Lotman's ideas in a different set of interrelationships in order to bring about a coalescence of his thought with that of Peirce. In Figure 2, notice that I have used the terms "heterogeny" and "homogeny" in place of "heterogeneity" and "homogeneity". I do so, above all, in order to set these two terms of from "hegemony", the Gramscian term having to do with conflict and negotiation between social groups and ideologies. "Hegemony" bears

${ }^{4}$ I use the Gramscian term in much the sense of Florencia Mallon as: (1) a "set of nested, continuous processes through which power and meaning are contested, 
most particularly on a struggle of opposites. This is chiefly the domain of Peirce's Secondness. If "hegemony" phases largely into category Secondness, then "heterogeny" phases into Thirdness and "homogeny" into Firstness. How so? In order to qualify myself, I should briefly define Peirce's sign. In a nutshell, Peirce's sign is something that interrelates with something for someone in some respect or capacity. The first something is the representamen (the signifying entity that usually goes by the name "sign"). The second something is the object of the sign. Someone, some semiotic agent or other, must be around to make or take the sign in order that it may develop as a genuine sign. If there is no maker or taker around, then the sign is no more than possibly or potentially genuine. What renders the sign genuine, in addition to its maker or taker, is that which brings the representamen into interrelation with its object and with someone in some respect or capacity. This is the function of the third component of the sign, the interpretant.

The representamen provides initial Firstness, the representamen's object, its other, introduces Secondness, and the interpretant provides the first stage of Thirdness. A sign that is similar to its object is an Icon (for example, a portrait). A sign with some natural or necessary connection to its object is an Index (a mercury column indicating temperature). A sign whose interrelation with its object is by way of social convention is a Symbol (the word 'book' as a sign of the physical entity, book). Notice, in this regard, the relative positions of Firstness-Secondness-Thirdness, iconicity-indexicality-symbolicity, and homogeny-hegemony-heterogeny in Figure 2.

Firstness takes on the characteristic of the sign, or representamen. The Firstness of the sign involves our immediately "experienced world", the world of feelings and sensations before there is any conscious awareness of some other, something other "out there" and other than the experiencing subject. Secondness plays the role of the object of the representamen — its other, the object with which it interdependently interrelates. "Socio-cultural necessity" constitutes

legitimated, and redefined at all levels of society. According to this definition, hegemony is hegemonic process: it can and does exist everywhere at all times", and (2) "an actual end point, the result of hegemonic process. An always dynamic or precarious balance, a contract or agreement, is reached among contesting forces" (Mallon 1995: 6). This definition of the term should render it adequately Peircean and processual; that is, non-binary. It should also demonstrate how Peircean triadic processes depart from the more dyadic framework Lotman customarily sets up (for example, Lotman, Uspenskij 1984: 3-35). 
the makings of the sign's Thirdness, the interpretant, the other of the other (we must keep in mind, of course, that the thin membrane between the terms is hardly more than the dynamic frontier delineating a small, temporary whirlpool from the entire semiosic movement from within which it arose).

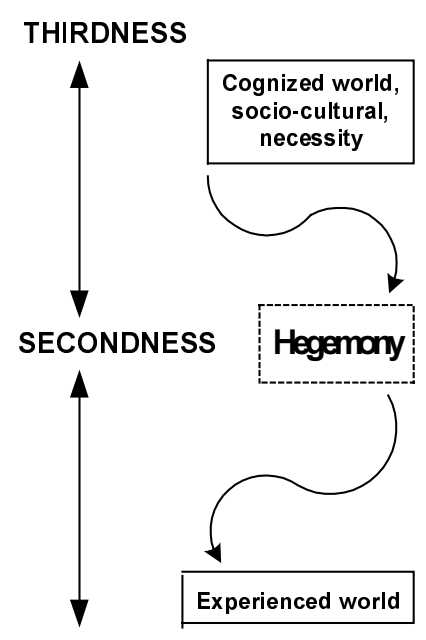

FIRSTNESS

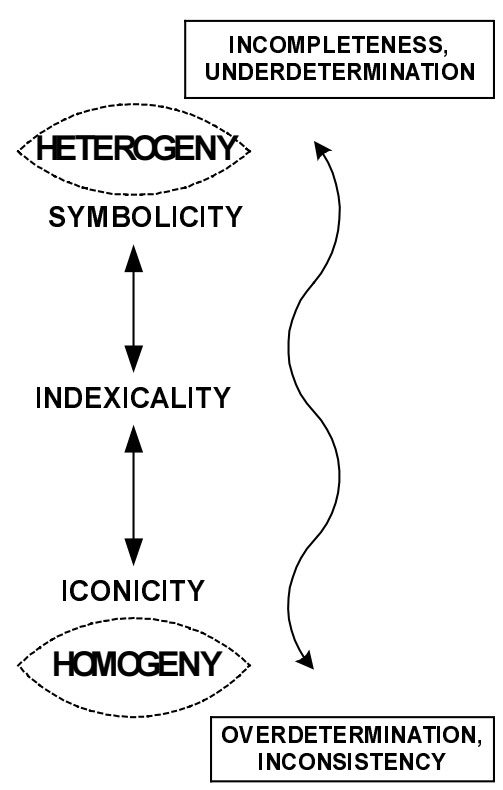

Figure 2. Interdependent, interrelated, interaction.

Now, consider the sign and the semiotic maker and taker or the subject as sign to be (1) in a swimming embrace with all its possible others as a matter of contingent happenings; (2) in apparent (I really must highlight the term) opposition to some actualized other as a matter of intransigent combat, dynamic struggle, rough-and-tumble agonistics; and (3) in intermediate, interdependent interrelation with its other other as a matter of dialogic exchange, renegotiation, and at times of happy consensus. Consider the more general picture in Figure 2, including item (1) as homogeny, (2) as hegemony, and (3) as heterogeny. Homo- qualifies the sphere of Firstness as a union of complementary contradictories into a harmonious package in terms of sheer possibilities without any pair of opposite terms having emerged 
to begin their mortal combat. Hetero- qualifies the sphere of Thirdness as sets of actualized terms that have either become bored or exhausted as a result of their incessant warfare and are now beginning a potential reconciliation of their differences. The suffix, -geny, indicates a manner of emergence, origin, organic becoming without reaching the stage of already having become. (And consequently, we now become more aware of the "biosemio-" nature of Figure 2.)

All this might appear as a trivial taxonomic game. So I really must more adequately specify what I have schematically mapped out before going on, to wherever and whenever that may be. But first, if I may be so allowed, I would like to indulge a bit more by illustrating the Peircean importance of my scheme.

\section{How better to qualify the social haves and the havenots}

Assume a given culture follows a particular standard practice. Let us call it ' $A$ '. This practice is handed down by the people in power as a code that must be honored, come what may. If I have a tendency to acquiesce and place credibility in anything and everything handed down by Authority, I obediently follow the received code, 'A'. As far as I am concerned, ' $\mathrm{A}$ ' incorporates culture as it is and must be. Consequently, I follow customary practices stipulated by ' $A$ ', and since I assume the origin of ' $\mathrm{A}$ ' is on the basis of those in Authority, whether in the hallowed halls of academic, the halls of legislature, or the workplace, I strive to follow it to the letter. In other words, my behavior evinces "hegemonic" affirmation. Peirce describes such acceptance of what one takes to be necessarily the case on Authority in his paper on "fixing of belief". ${ }^{5}$ He discarded knowledge via Authority in his anti-Cartesian argument that there is no guarantee whatsoever that it will put us on the straight and narrow path toward knowing.

In contrast to ' $\mathrm{A}$ ', that I follow rather blindly, I might rebel by denying the standard practice. This is tantamount to saying: 'Not-A'. This is "hegemonic" denial. I may now be exercising Peirce's tenacity, the method of the rebellious upstart who goes his own way without any regard for authority or the helpful suggestions of anyone

${ }^{5}$ I refer to Peirce's three articles on cognition in presenting his anti-Cartesian argument, where he presents the pitfalls of knowledge by way of authority, tenacity, and apriorism or introspection, and opts for knowledge by way of general agreement on the part of the entire community (CP: 5.213-357). 
else in her community. This, for obvious reasons, will rarely lead me to any legitimate answers, since my own idiosyncratic way has little chance of becoming general community practice, hence I remain isolated or I am ostracized in one form or another. If I take on unwarranted self-importance I may go so far as to espouse the Cartesian a priori method of introspection like some privileged individual who spreads the word about his having plumbed the depths of his consciousness, survived, and returned with the grounding bit of knowledge in hand. Peirce's anti-Cartesianism simply will not let this concept fly, however. There is no knowing, ultimately knowing, who is to be trusted and who not. Why should we blindly trust anyone and abide by his counsel without questions or the opportunity for a good counterargument? Peirce's prescribed road to the best of all possible worlds of knowing rests in amicable conversation, banter, debate, kibitzing, and even agonistics when it becomes necessary.

This is the dialogic way toward knowing. It entails neither necessarily ' $A$ ' nor necessarily 'Not-A', but most likely something else, something new, some "heterogenic" practice that has emerged from the erstwhile excluded-middle between ' $A$ ' and 'Not- $A$ '. This "something else" is what emerges within the community out of dialogic give-and-take. During the dialogue, what is accepted becomes caught between the horns of some dilemma or other, and something must give. But upon giving, something else emerges, which is then put to the dialogical or practical test, and hopefully some general opinion will ensue. And where did this "something else, something new" come from? From the range of possibilities, from within Firstness, or the sphere of "homogeny", from which all the "heterogenic" alternatives between 'A' and 'Not-A' can emerge.

Now, I would invite you to take a wild flight of the imagination with me, a sort of "thought-experiment", if you will. Thought experiments can at the outset be considered either consistent or inconsistent, depending on the reigning theory, the perceptual and conceptual mode of the audience concerned, and the general temper of the time. According to an Aristotle-style thought experiment, a quarter should fall faster than a dime since it is heavier. Fine. The common sense of Aristotle's time would in all likelihood tell most respectable citizens so much. So what if we attach a dime to a quarter and drop them. Would they fall faster than the solitary quarter since they make up a heavier package. Well, that is actually somewhat problematic. Since the unattached dime would fall more slowly than the quarter, when the two are connected, the dime should act as a drag on its partner and 
slow its ordinary progress down somewhat. So the combination of the two coins should fall slower than the isolated quarter. But the combined pair of objects is heavier than the quarter, so they should fall faster. But they don't. Needless to say, Galileo demolished this theory with an alternative series of untested thought experiments (of course it is doubtful he ever actually carried out his experiment from the top of the Tower of Piza). And as a consequence of Galileo's work, in our day we believe we have a relatively consistent theory, unlike those naive Greeks. So far, so good. An inconsistent theory was properly discarded and replaced by a more logically and rationally respectable alternative, and sober-minds managed to prevail. In another way of putting the matter, Galileo said 'No!' to authority, to 'A'. He said: 'Not-A!' Then he went about finding an alternative between the ' $A$ ' and the 'Not-A'. Eventually, something other, something new, emerged from the semiosic soup of possibilities, Firstness, "homogeny", and the entire scientific edifice become increasingly more "heterogenous" rather than merely Manicheistic, dualistic, and "hegemonic".

In our century, physics in the form of quantum theory, especially when carrying the labels of Heisenberg's uncertainty principle and Bohr's complementary, became brazenly, and apparently without remorse or regrets, ambiguous, and even inconsistent, depending upon the perspective. At a given moment is a quantum "event" a "particle" or is it a "wave"? To put the matter quite baldly, the only possible responses to such questions is 'Yes, but no', 'No, but yes', 'Yes and no', 'Neither yes nor no'. This is perplexing, to say the least. In Galileo's "Dialogue", Simplicio the Aristotelian disrespectfully asks Salviati: "So you have not made a hundred tests, or even one? And yet you so freely declare it to be certain?" Salviati responds: "Without experiment, I am sure that the effect will happen as I tell you, because it must happen that way" (Galileo 1967: 145; in Brown 1991: 2-3). This recalls Einstein's remark regarding physicist-astronomer Arthur Eddington's experiment designed either to verify or falsify Einstein's general theory of relativity. When asked his opinion about the possible outcome of the event, Einstein responded that if it appeared to refute his theory, then he was sorry for the dear Lord, because the theory was correct. A marvel of arrogance? Yes ... and no. Such declarations bear witness to the power of the mind and the confidence of she who dwells within it. It also testifies, I would respectfully submit, to the inextricable union of Firstness-Secondness-Thirdness, representamenobject-interpretant, iconicity-indexicality-symbolicity, and feeling- 
sensing-interpreting. This union can hardly be put to the test, like Aristotle's or Galileo's thought experiments could have been had their authors been so disposed. Yet Hume, Locke, and others, including Peirce, bear witness to the impossibility of one's observing oneself in the act of observing oneself in order to distinguish roughly between the equivalent of Peirce's categories. It's roughly tantamount to the quantum "event" just described.

It seems that, with respect to this mutual embrace of Peirce's intriguing triads, and in light of his anti-Cartesian posture as outlined above, the counsel might be: never bow to authority unless it is deserving of your respect, do not blindly push forth come what may with paranoid tenacity, beware of those false prophets bearing tidings of their having been to the wilderness of their introspective mind where they saw the light of Truth, but pay your dues to the community of your choice, keep the dialogue open, and do the best you can. With respect to the triads themselves, we would have it that the imaginary thought-sign is the possibility of ' $A$ ', a might be from the "homogenic" sphere of 'Both A and Not-A'. In this regard, the object of the sign would be an "anti-hegemonic" 'Not-A'. And the interpretant would be a "heterogenic" 'Neither A nor Not-A', but since it brings ' $A$ ' and its respective other into a three-way mediation, it potentially gives rise to the emergence of something different, something even possibly new. We can construct Figure 3, with the "point" or "vortex" connecting each of the "sign" components, such that it can be mapped into Figure 1.

The "vortex" is the composite of all unactualized signs. It is, so to speak, the "emptiness", the sheer possibility of anything and everything. It is as if we had 'Both A and Not-A' and 'Neither A nor Not-A' written on the two sides of a strip of paper and then we make of the two-dimensional sheet a Möbius-band in three-dimensional space to yield 'Both of the propositions', and 'Neither of the propositions'. Moreover, the choice is not a choice between Aristotelian truth and falsity, between what is on no uncertain terms true and what is not true, between what exists and what does not exist, but rather, between what from some context or other might be possibly true and what might be possibly false, and what might possibly be neither true nor false because it not yet is: there is only something like what Peirce (CP: 6.512) calls a "cut" or G. Spencer-Brown (1972) a "mark of distinction". There is no more than our "tripod" plus the "vortex".

This "cut" or "mark of distinction" makes up what Gregory Bateson (1972) terms a "difference that makes a difference". In the 
beginning, demarcating line is set down separating "this" from "that", "inside" from "outside". Then other distinctions are made, and then still others, and so on, toward ever increasing complexity. Lotman writes that every culture

begins by dividing the world into 'its own' internal space and 'their' external space $[\ldots]$ The boundary may separate the living from the dead, settled peoples from nomadic ones, the town from the plains; it may be a state frontier, or a social, national, confessional, or any other kind of frontier. (Lotman 1990: 131)

Lotman refers to this division as binary. I would beg to differ with him in this respect. It is, more appropriately, trinary or triadic, following the Peircean model of the sign depicted in Figures 1 and 3. How can this triadicity come about as a result of a binary division between "this" and "that"? As in Figure 4, I would suggest. The sign tripod collapses to a point, the original "vortex", the "emptiness" giving rise to the emergence of the sign, of all signs, of all that is becoming. Then the point, by repeating itself over and over again, becomes a line, the "cut", the "mark of distinction". That is to say, two-dimensionality collapses into zero-dimensionality that becomes one-dimensionality that separates two semiotic spaces of two-dimensionality.

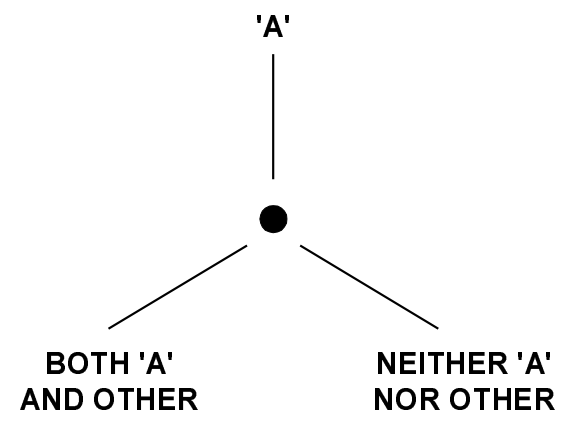

Figure 3. Always, alternatives.

Lotman writes that:

The asymmetry of the human body is the anthropological basis for its semioticization: the semiotics of right and left are found just as universal in all 
human cultures as the opposition top and bottom. And the fundamental asymmetries of male and female, living and dead, are just as widespread. The living/dead opposition involves the opposition of something moving, warm, breathing, to something immobile, cold, not breathing (the belief that cold and death are synonyms is supported by an enormous number of texts from different cultures, and jus as common is the identification of death with turning to stone/ see the numerous legends about the origins of mountains and rocks). (Lotman 1990: 133)

Lotman's words might strike one as pure and adulterated binarism. Actually, in every case the binary implies the "vortex" of "emptiness" and meaning, that is, the point at the center of Peirce's semiotic tripod (that which contains the possibility for all semiotization) and the interpretant (meaning). Right and left imply existence of the body, male and female imply the notion of gender, living and dead imply the universal principle transcending life. And so on. The "vortex" there will always be, for if not there are no signs. And the third leg of the tripod, the interpretant, there will always be, for if not, if there are no sign makers and takers, then there is no genuine semiosis. Because semiotic space "is transected by numerous boundaries, each message that moves across it must be many times translated and transformed, and the process of generating new information thereby snowballs" (Lotman 1990: 140).

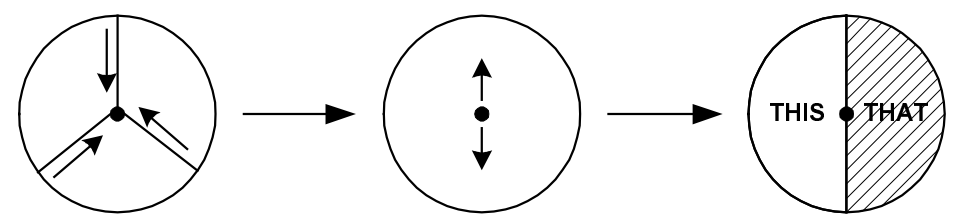

Figure 4. How the semiotic tripod divides.

But, ... this is not very clear, I fear. But what more can be said if what is to be said cannot explicitly be said? It only lends itself to a sort of feeling for what is on the tenuous cultural track of semiosis. There is no Cartesian clarity to be had at this "nonlogocentric", "nonlinguicentric" sphere of vague and overdetermined possible signs where nothing is distinct and where there are no sharp lines of demarcation.

Back to a few more concrete examples, then. 


\section{A picture puzzle of $\boldsymbol{n}$-dimensions and uncountable pieces}

Latin America cultures, it goes without saying, are a complex, virtually chaotic, "logic" of ethnicity and culture, conquest and postcolonialism, virtual identity and radical difference, imitation and distortion, conflict and co-optation, antagonism and reciprocity. Whoever surfaces to the top of the gush of ongoing cultural becoming in the beginning might appear to have gained the upper hand. But not necessarily. That is, unless she might have been able simultaneously to perch on the shoulders of all those below and maintain a paternalism-patronizing hegemonic relationship with them. She who happens to be of the haves at the top depends upon those havenots below and they in turn depend upon her.

In the beginning, the forging of Latin America seemed to be the product of clear and distinct delineation. Answers were straightforward, and no further questions were asked. Or so it seemed to many. However, take the case of an imaginary Amerindian from the central plateau of Mexico. If when asked who "discovered" America he without hesitation says "Why, your ancestors, of course", he is either consciously or tacitly giving a nod to the "superiority" of Europeans over pre-Hispanic civilizations. In other words, he is manifesting his co-optation into the colonizing system and turning his back on his own heritage. This is cultural awareness like it "should be" according to the hegemonically endowed haves of the conquest and colonization and the aftermath of independence. If, on the other hand, our Amerindian retorts: "Well, Patrón, as I see it, according to your account, Columbus 'discovery' America, but actually, we had no need of anybody to 'invent' us and tell us who and where we were", he questions the supremacy of the "discoverers" and subverts the very idea of "discovery" (to reveal, to be the first to know). His response is quite properly counterhegemonic. It is as if to say 'No!' to the colonizing system, depending on whether we are taking strict classical logical principles into account or the pragmatics of human communication. As far as he is concerned, there was no "discovery", for nothing was concealed so that it might be revealed. There was no unknown in waiting expectation of its being placed in the light of knowledge.

A response to a comparable question regarding the problem of identity might be exceedingly more complex for a mestiza woman (of mixed racial and ethnic heritage) from the same area of the country. Part of her heritage is native American, another part perhaps African 
American, and another part Castillian, which is itself streaked with Arabic cultural presuppositions and propensities, perhaps along with a little Roman, Celt, and so on, influence. The matter of her cultural heritage, her identity, her proper posture vis-à-vis the pressures of today's neoliberal, postmodern consumerism become a mixed and confusing bag of tricks. One might tell her that she really should choose. She should choose who she is, what her attitude is to be with respect to herself, her background, her political inclinations, her behavior and relations with others in society, her role in the economic life surrounding her - what she will purchase and what she will be willing to do in order to purchase more, and how she will use it - and so on. Indeed, the choices are hers, and to decline exercising her right to choose is itself also a choice that will have its own effect on her. Whichever choice or set of choices she arrives at, she will remain separated and at the same time integrated; she will adopt and she will reject; she will embrace and she will resist; she will interrelate and become part of an interlocked concoction of conflicts and contradictions. Along these lines María Lugones writes:

\begin{abstract}
If something or someone is neither/nor, but kind of both, not quite either.
If something is in the middle of either/or,

if it is ambiguous, given the available classification of things,

it is mestiza,

if it threatens by its very ambiguity the orderliness of the system, of schematized reality.

If given its ambiguity in the univocal ordering it is anomalous, deviant, can it be tamed through separation? Should it separate so as to avoid taming? Should it resist separation? Should it resist through separation? Separate as in the separation of the white from the yolk? (Lugones 1994: 459)
\end{abstract}

Yes, choice. We are condemned to the imperative of choosing, whether we know it or not and whether we like it or not. The choice exists between the either and the or, that is, between both the either and the or, or rather, what is between the either and the or. But... No. Not that, I'm afraid. Not really, for there is nothing between the either and the $o r$. But ... that's not right either. Not really. In a metaphorical manner of speaking, "emptiness" is "between" them: nothing and everything, as possibilia. The emerging mergence of both the one and the other is declaring 'Both A and Not-A'. Poking around in the interstices at the risk of falling into the very slightly, in fact infinitesimally, parsed mouth of 'emptiness', and one might perchance enter that never-never land where 'Neither A nor Not-A' is the case, and 
there is a ray of hope that something novel might emerge - the selforganization of all things, all things as organism, as benign signs of ongoing resonance. It's all a process, a marvelous process, and she, that is, our 'enchanting' and 'enchanted' mestiza, is in it, as are all of us. What she is, is not what she is, and she both is and is not what she $i s$, and she is neither what she is nor what she is not; and she is all of the above and she is none of the above.

Riddles! Is there no way out? But who promised us a comfortable road to truth by means of binary either-or logic anyway? Who told us there must be either discovery and knowledge or eternal darkness? A matter of dominating or of subservience? Of raping nature or living a sordid animal existence? Of razor-sharp binary choices between eithers and ors? Of course Galileo and Bacon and Newton and Locke and Descartes, and later Thomas Edison and Henry Ford and Bill Gates and many others, and a host of celebrities of various sorts in their own way, all give us an image of that machine-oriented, materialistic, consumerist good life. From another direction, a concoction of religious saints, seers, and assorted sinners also promise milk and honey. As do those who "discovered, conquered, and colonized" America, and Hitler and Mussolini and Stalin and a few Latin American revolutionaries and visionaries and populists who belong to the same crowd. Where did it all get us? Within the last century we have been warned by Nietzsche and Heidegger and Wittgenstein and Foucault and Derrida, and their critics and disciples that the promised paradise is a sham. And we have the limitations on our knowledge by way of Heisenberg and Bohr and Gödel and their counterparts in science, logic and mathematics. Any and all answers to all questions eventually meet their others, and eventually there may be a happy meeting ground, or some alternative or other may pop up between the neither and the nor, and then it may be a matter of all of the preceding ... or none of it. Yes, riddles. Yet, in spite of it all, liberation, which, though at the outset it may appear perverse, is over the long haul quite healthy.

What is for sure is that, with due respects to Lotman, binary thinking must go the way of the dinosaurs, for if not, it is most likely we who will follow them into oblivion. This is especially the case of the most complex processes the likes of cultural comings and goings. Cultures, "hot" and "cold" and modern and postmodern alike, are comparable to pervasive "strange attractors". They are nonlinear, interrelated, unpredictable. Their virtual Brownian motion is the result of the dependency of every part on every other part, and if deter- 
ministic laws there be, they are beyond the pale of human cerebral capacities. Cultures are processes, never products; they are codependently arising becoming, not cause-and-effect sequences; they are events, not things moving along like trains on a track; they are perpetually self-organizing into unseen and unseeable wholes, rather than predictable wholes and their parts in terms of static and statistical averages. They are semiosis at its best, though, unfortunately, occasionally at its worst.

Yet binaries continue to rule the roost in many quarters. Cultures are for some reason or other still seen as hardly more than oppositions between the powerful and the helpless. The idea generally has it that the powerful form a bloc; they are unified, quite stable, concordant, and allied toward common economic, social, political, legal, moral and aesthetic goals. The weak, in contrast, are diverse, dispersed, diasporic, discordant. The haves are into structure, control, domination, manipulation; the havenots are reduced to a diversity of interests, with no central organizing force (for example, Hall 1981). John Fiske (1989a) dubs the power-bloc homogeneous and the people heterogeneous. He compares the former to Mikhail Bakhtin's centrifugal forces and the latter to centripetal forces, conceding that the opposition is actually more like the dynamic conflict between an occupying army and "cultural guerrilla" activity, following the work of Michel de Certeau (1984). The struggle, we read, is always a confrontation between legato or hegemonic forces of homogeneity and the unruly, staccato or heterogeneity of the people's weak and usually futile hits and misses. Yet, distinctions cannot be so clearly demarcated. As we have noted and will note with greater emphasis, the havenots actually enjoy a "cultural guerrilla power" that invariably pushes new terms into the gaps between erstwhile opposites.

Those in power generally tend to put things in a straightforward way, simply providing the information in order to reap profits. The sober-minded somnambulistic folks tend to take what is ladled out to them with neither questions nor much creative input. The wily "cultural guerrilla-minded", in contrast, nimbly catch the ambiguities of the system and use them to subvert it in the only way they are capable. The power-bloc, of course, uses a combination of methods. For example, jeans ads might have a rugged Western scene, or they might give the idea of frolicking young people having fun, with hardly a hint that the objective is to sell you a pair of pants. Ads can cross barriers, such as Bill Cosby convincing you you should eat more Jello pudding in a commercial break during The Cosby Show. Such ads also 
leave themselves open to "cultural guerrilla" activity. A giant billboard for Uniroyal tires once depicted a Latin American kid with a Walkman plugged into his ears and sitting on the desert floor next to a pair of tire tracks under the caption: "He only knows three words of English - Boy George and Uniroyal". Some "cultural guerrillaminded" subvert painted over "Boy George" and "Uniroyal" and replaced them with "Yankee go home". The ad mixed otherwise discordant images for a specific purpose; the tables were turned in order to bring consonance to that same image. Examples are virtually uncountable, of course, and I trust I need not press the issue further. The upshot is that the powermongers strive to make everybody alike (homogenous) and to entice them into doing the right thing in conformity to their own motives. Those well-meaning citizens who are robotic of mind tend to play along with the game. The "cultural guerrilla" subverts, on the other hand, distort the system in whatever way than can and create (heterogenous) differences, which can give rise to alternatives that may then be assimilated into the system or not, however the possibility for the exploitation of these differences may be interpreted.

In short, according to one story, money talks, might makes right, and status is everything. That story is the power-bloc's favorite. Everybody is there to fulfill his respective role, and with a few constables around, the ship's order is maintained. But this is a binary view of things. I exists in contradiction with the Peircean triadic nature of semiosis. The other Peircean nonbinary story has it that the orderly phalanx marching in step to the beat of the big band is to a greater or lesser degree constantly thrown into disarray by the upstart subverts. The first story, the binary story, falls comfortably in line with the traditional hard-line view of science: what is of worth is that which is universal and unchanging, that which is solid and lasting; what changes is of ephemeral value and unworthy of serious attention. However, according to the recent view, originally pioneered by philosopher Karl Popper, science is good precisely because it is open to change, because there are always a few "guerrilla" scientists lurking around. In fact, it is at its best when in constant war with itself, and it progress most effectively by revolutions and internal conflicts (Agassi 1975). 


\section{There are battlefields where we least expect them}

Not only is science perpetually at war with itself, so also are many of our most cherished inductively derived beliefs. The real problem is that not only are these beliefs more often than not binary based, they also engage in either-or binary warfare among themselves.

Perhaps the most succinct way to put the issue is by evoking what is known as the "paradox of induction", developed by Carl Hempel (1945). In a nutshell, the tale goes like this. We could assume "All swans are white" and attend to our daily affairs quite effectively without ever becoming aware of any anomalies or alternatives. It is simply true to say "All swans are white" and false to say that "Some swans are nonwhite", and that's that: case closed. It is ideally an either/or binary matter. We have an ingrained feel (Firstness) for the whiteness of swans, and we could hardly feel otherwise, unless in some imaginary world.

However, a certain explorer down under, namely, Captain Cook, once found - that is, sensed (via Secondness) and interpreted (via Thirdness) - some swans as black. Henceforth the categorical borders suffered a change. It eventually became known that "Most swans, but not all, are white; those nonwhite, that is, black, swans can be found in a remote region of the globe, namely, Australia". Instances like these led Popper to declare that if you look for positive evidence for a general proposition you will almost always be able to beat the world into submission and "discover" your evidence. So looking for positive evidence is no big deal. What is important is looking for negative evidence that will change customary ways of thinking and of looking. In other words, you should expect to be surprised by the unexpected, and then you can give a nod of acknowledgment that you are not surprised that you are surprised when an expected unexpected event turns up. Consequently, you alter your expectations somewhat, and continue on your way expecting another surprise somewhere along the road that will thwart those newfound expectations. If you want to learn something, don't just see everything and say everything as repeats of what presumably was, is, and will be, but look for mistakes, differences, events that weren't supposed to happen.

In this manner, it should not be at all shocking that "All swans are white" did not withstand the test of time. In fact, it was to be expected. This goes to show that in the sphere of possibilities for all events, 
seeing and saying must imply the statement: "Swans are white and they are nonwhite". One pole of this contradiction was held true during one period of human history, the other pole during another period. So if "Swans are white and they are nonwhite" is taken to be atemporal, then "Either swans are white or they are nonwhite" is atemporal in another more limited sense, for, logically speaking that is, in terms of classical logic - either one or the other is viewed as immutable, depending on the time and the place and the folks involved. However, we also have the implicit statement: "It is neither the case that all swans are white nor is it the case that no swans are nonwhite". That is to say, previously "All swans are white" was the case, but it is now the case that "Most swans are white". And it was previously the case that "No swans are nonwhite" but it is now the case that "Some swans are nonwhite, specifically, those that are black". From this rather unkempt sphere where events, seeing, and saying, is neither timelessly one thing nor the other but potentially something else, something different, we have temporality. Given our temporality, we have one thing at one time and another thing at another time, with both things thrown into the same bag as part of a vast ocean in constant self-organizing movement wherein it is perpetually becoming something other than what it is. ${ }^{6}$

So we have, at one extreme, (1) "Both white swans and nonwhite swans", at the other extreme, (3) "Neither exclusively all white swans nor no nonwhite swans", and in the middle, (2) "Either white swans or nonwhite swans" (i.e. all from Figure 2). (1) is the sphere of unactualized possibilities in harmonious intermeshing, no matter how contradictory, (2) is the sphere of classical logic, and (3) is the sphere of emerging novelties between the either and the or. (1) is qualified as exceeding vaguenes; it is fraught with contradictions any number of which can over time be actualized, hence it is overdetermined (notice how the terms are used in Figure 2). (3) is marked by generalities arising from the particulars actualized from (1) and passing through (2); it is invariably incomplete, since there is no knowing when and where something new and different will emerge to take is place between two already actualized general conceptualizations, hence it is underdetermined. Given the above considerations, (2) is under most circumstances the dwelling place of binary practices as they are

${ }^{6}$ The above is another way of putting Peirce scholar Charles Hartshorne's (1970) view that temporality begins to emerge within Secondness and comes into full bloom within the sphere of Thirdness. 
customarily articulated: there is either the haves or the havenots, locked in an apparently eternal, timeless, synchronic struggle. (1) may be labeled homogeny. (3), then, is heterogeny, since between any two general terms or statements there always exists the probability somewhere and somewhen of something else emerging, hence the system is perpetually moving toward the completion of its own continuity without ever realizing that goal. ${ }^{7}$ Focus obsessively on (2), and you have the makings of binary, "linguicentric" practices, the pathway of least resistance the somnambulistic yes sayers customarily trod.

Now, allow your attention nomadically to wander over (1) and (3), and you begin to "resonate" with the tossing, rolling, heaving tide of semiosis, which includes "cultural guerrilla" strategies. You are also coming to an awareness of the unspecifiability of this "resonance". You can't clearly and distinctly say what you think about the hegemonic cultural milieu outright; at best, you can only feel it, empathize with it, bring it into rapport with your general understanding. Consequently, you might find yourself on the path of "cultural guerrilla" activities. I wrote "find yourself". That's an overstatement, actually. From within your "cultural guerrilla" mode of bucking the waves, kicking at the pricks, swimming cross stream, you will engage in your somewhat subversive activity because of your gut feelings and proclivities. Your behavior will be what it is because that is how you feel, often without your ability precisely to articulate your actions and reactions. It is as if you were a natural born "cultural guerrilla".

Back to statements (1), (2), and (3) and their counterparts in Figure 2 for a moment.

\section{Little signs within the inconceivable big picture}

Bringing about a happy emergence of (1) and (3), and of homogeny, hegemony, and heterogeny, we have either inconsistency or incompleteness, or perhaps both, by the good grace of Kurt Gödel's proof that spelled the limitations of logic and mathematics, and by extension of the sciences, the humanities, and in general all human communication. The upshot is that we cannot help but spout out unexpected contra-

\footnotetext{
${ }^{7}$ The goal can never the reached, for, as Peirce had it, it is an infinitely receding horizon that can be no more than approximated by asymptotic movement comparable to Zeno's Achilles moving in on the tortoise in the race in an infinite series of successively smaller increments (however see Hesse [1980] for a critique of this view).
} 
dictions and occasional paradoxes, and no matter how much we manage to say about some particular aspect of our world, our saying will always be incomplete.

Sign processing within these limitations is a dialogical community affair. Peirce writes that whenever a sign is vague (inconsistent) it is up the to maker of the sign to render it a bit more precise and in the best of all worlds hopefully to clear up the inconsistencies. On the other hand, in order that the sign's nature as a generality may become properly acknowledged, the sign's taker must enter into the game, interacting with the sign, with its maker, and with the entire ambient, in order to bring the sign's meaning a tad closer to its completion but, as pointed out above, the sign's meaning never stands a chance of completion in the genuine sense (CP: 5.505). Hegemony as a dualist practice of the sort we might expect to find in (2), could well culminate in the empowerment, the enfranchisement, of those who have the proper pull and know how to engage in the most advantageous but ruthlessly aggressive practices. Within this sphere we might encounter the makings for paternalism, patriarchy, patronage, and such practices in this stark desert of dualistic cultural values.

This is a stringently limited view, however. Vagueness and generality from a broad cultural view paints another picture entirely. In order to put this picture in focus, consider, once again, Figure $2 .{ }^{8}$ In the first place, I use reversible arrows of various sorts to emphasize the fluid character of all the categories involved. This is no indication of linearity or isotropic timeless time, however. The categories, usually coming in threes rather than twos, are placed at various levels to depict their fuzzy codependent interrelationships and their nonlinear, time-bound, self-organizing nature, though, I must hasten to emphasize, no hierarchy of dichotomous terms is implied here. The general movement is from signs of vagueness toward acknowledgement of classical logic and "styles of reasoning" and then to the construction of perpetually incomplete generalities, universals, taxonomies, and hierarchies. ${ }^{9}$ Inconsistency below might be hopefully abandoned, and progression upward might hopefully be toward the fulfilment of those fond and familiar dreams of the good life, social

${ }^{8}$ It bears mentioning at this juncture that I have availed myself of the overdetermination-underdetermination and inconsistency-incompleteness and vaguenessgenerality scheme in various previous studies with respect to Peirce's basic sign types, our sensory modes for perceiving signs, and our sign interpretation (Merrell 1995a, 1996, 1997).

${ }^{9}$ The idea of "styles of reasoning" is from Hacking (1985, see also Merrell 1995a). 
justice, emancipation for all, and complete and consistent knowledge. Given the underdetermination factor, however, there is no utopia to be had. In other words, the plenitude of all things is a pipe-dream, for there is no royal highway to the land of milk and honey. Homogenyheterogeny are here to stay, whether we know it or not and whether we like or not.

All this has further bearing on Peirce's categories. Firstness is the mode in which something is as it is irrespective of anything else, such that it would not make any difference if nary a thing else existed, for it is self-contained and self-sufficient. This mode is apprehended not by intellect or as a result of sensations received from the big wide world out there, for, simply put, there is no other mode that could be perceived or conceived in relation to Firstness. There is only Firstness. Firstness is also without parts, for if there were parts there would be something other than the whole of Firstness. The whole of the Firstness is a melding of everything that makes it up. It is without clearly delineable features; it is vagueness of the most vague sort. Imagine a combination of vibrations in the air that according to Fourier analysis produce in their composite high $C^{\#}$. You hear the note and nothing else, you feel it, and this feeling is perpetuated, one second, two seconds, then many seconds and minutes, without its being related in any form or fashion to any other sounds. You simply feel it as it is, no more, no less. Now imagine you are the subject and the sound is the object, and by listening to the high $\mathrm{C}^{\#}$, by sensing it and perceiving it, you enter into it as a result of many years of your own musical appreciation and actual practice. Your recognition of high $C^{\#}$ as just that, high $C^{\#}$, is an act of reaction and interaction with something other than yourself. It is otherness, the otherness of Secondness, of indexicality. Everyday living is pervaded through and through with such action, reaction, and interaction with ephemeral items of our surroundings, with tokens, items as they pop up on the stage before us, the stage we are on. Thirdness, on the other hand, is a general matter. The high $C^{\#}$ note is recognized as such in terms of its being related to and distinguished from any and all other notes in the repertory of your knowledge of music. It is now not merely this note here and now, but high $\mathrm{C}^{\#}$ as a type, a general category. The note as a type is a modification of its feeling and of its perception as such-andsuch an item from among a range of other items to which it is related. It is acknowledgement that the sound belongs to a general category that gives it its character insofar as that character is susceptible to an account by means of symbolic signs, words, language. 
This hybrid view of knower and known is gradually coming into view. It is now taken for granted that Gramsci's concept of hegemony made it possible to move beyond the dualistic idea of power brokers imposing their values on helpless and hapless common people. This switch has been a long time in coming, however. Amongst leftist writers the old fad had the dominant classes in control and the popular classes as victims. In later years, especially given hegemony theory, the popular classes were looked on positively as a group with virtually unlimited resources and capacities to manifest their defiance and in the process provide alternatives to the stolid, stultifying ways of the dominants. Such obsessive focus on extremes in order to erect dichotomies is discomforting. The problem is that, in anthropologist Néstor García Canclini's words:

there is so much insistence on the juxtaposition of the subaltern and hegemonic culture and on the political necessity of defending the independence of the subaltern culture that the two come to be thought of as two quite separate entities. With the presupposition that the task of hegemonic culture is to dominate and that of the subaltern culture is to resist, much research has had no other aim than to inquire about the ways the two distinct roles were carried out. (García Canclini 1984: 48)

In this sense, obsession with either one or the other of the horns of the presumed opposition is binary thinking, in spite of the concession that the subalterns might enjoy more power to alter the system than was previously thought. This Manichean tendency is certainly not vintage Gramsci; he resists facile dichotomies. There is not merely power, but also seduction, complicity, negotiation, subversion and covert, "cultural guerrilla" action.

Gramsci teaches that what meets the eye is often not as clear-cut as it appears. He ties the notion of popular culture to the subaltern condition and at the same time reveals the complexity of these ties. The dynamic interaction between subalterns and the dominant class, as pointed out above, makes for constant shifting of postures and strategies such that the interrelations are best qualified as process. There is no standing still; everything is in perpetual movement. Consequently, the subaltern's admission of hegemonic power is not necessarily an act of submission, and her rejection of that power is not necessarily resistance. All expressions from the haves are not always the manifestation of irresistible hegemonic forces, and the passive response of the subalterns is not simply a bow of the weak to the strong. Nor is the exercise of hegemony merely a product of the 
inculcation of Pierre Bourdieu's habitus in the people such that they respond the way they respond because they can't really respond otherwise (Bourdieu 1990; Bourdieu, Passeron 1977). Creative responses on the part of the people, in de Certeau's (1984) conception, keeps the social organism's heart pounding and lungs heaving. In the final analysis, popular culture is above all creative.

Given their creativity, what the people believe, buy, and consume, cannot simply be subsumed within a binary logic of domination and subservience. The dominant rationality would have it, nonetheless, that the people behave and consume in such a way that they all become one homogenous soup (from homogeny, not homogeneity). The subalterns gravitate toward homogeny, while the dominants move up slightly toward the world of heterogeny, in order to highlight their distinction from those others and to refortify their power. Yet the subalterns, given their de Certeau role as "cultural guerrillas", create differences of their own upon expressing their contempt for their lot in life. They sweet talk their superiors and play up to them; at the same time they cheat a little, mix things up in order to alter them, bring spice to life, and subvert the motives of the hegemonic haves. In so doing they are not simply liars, thieves, and rebels obsessed with overturning the system. They are engaged in practices on a small scale compared to the megalevels of lying, thieving, and subversion going on at the upper levels. They are simply doing the best with what they have. Hegemony is in this sense most proper to Secondness and heterogeny to Thirdness. But these categories did not simply spring out of a vacuum. They existed in interrelated, interactive, codependence within the sphere of homogeny, Firstness, wholeness. Within homogeny, there are parts, to be sure, but they are possibles, they are not (yet) actualized for a particular mind. The parts remain melded into one, that is, they make up a collection so vast that in terms of themselves as possibles there is no room for them to retain any form of distinction or individualism, so they are welded into one another, they are annealed. Firstness is the continuum of all that is possible. It is like a ring, with no conceivable beginning or ending and no middle. As Secondness emerges into the being of the becoming and the becoming of the being of signs, the ring is cut, severed, such that there is now one side and the other side and the border of borders in between. And the chain of Seconds has begun its becoming, the task of which then begets Thirds, and more Thirds. There is no conceivable end of semiosis, nor is there any conceivable beginning, or center.

Now, for an illustration of self-perpetuating semiosis, if I may. 


\section{How subverting signs emerge}

In 1977 in the historic Plaza de Mayo of Buenos Aires and site of the presidential Casa Rosada, the women's sudden appearance was hardly noticed except by the secret police of the military government.

At first there was only a handful of women walking around in flat shoes and wearing kerchiefs over their heads. They appeared uncertain, even frightened (after all, Argentina was ruled by a repressive dictatorship that lasted from 1976 to 1983 and 'disappeared' some 30,000 citizens and tortured countless more). They wore photographs of missing family members on their dresses. They came from every social class to fight the Armed Forces, the politicians, the Clergy, the complacent press, everybody, in order to get some answers. The handful of women gradually grew to fifty, then hundreds, and then more than a thousand. Tourists began asking questions, that embarrassed the state. But the women went virtually ignored by government officials. Their visits to the Catholic Church in search of support yielded no results: its complicity was obvious. The government continued to pay the women hardly any mind. Yet, they persevered. As time went by, they became known as the Madres y Abuelas de la Plaza de Mayo ('Mothers and Grandmothers of May Square'). ${ }^{10}$ While the 1978 World Cup soccer championship team was honored, the women protested. When progovernment youths, whipped into a frenzy, spat insults at them, they asked questions. Eventually, moral outrage ensued. In 1980 the Argentine human rights movement became involved, especially after Adolfo Pérez Esquivel was awarded the Nobel Peace Prize. In 1981, workers began protesting inadequate wages, working conditions, and housing. In 1982 they joined the protesting mothers, and in that same year the press took a more active role in criticizing the government. The humiliating Malvinas/Falkland war came and went. And finally, in 1983, the military brought out and dealt its last deck of cards. Elections were held, a civilian became president, and the military, as a final coup, granted itself amnesty from all human rights violations!

This train of events is perhaps one of the best examples of honest, sincere, patriotic subversion on the part of subalterns from among subalterns: women, as "cultural guerrillas", taking on a role with few precedents. It is also living proof that the subalterns by peaceful means can create alternatives and impose them on the dominants.

\footnotetext{
${ }^{10}$ See Agosín (1992), Bouvard (1994).
} 
Subalterns interjected the homogeny of hegemony with a massive dose of heterogeny, and the system finally caved in. Iconicity raised itself to the level of indexicality by signs pointing toward the presence of absent individuals, and silent icons and indices proceeded in the direction of symbols, that were eventually forthcoming. Firstness engendered Thirdness, subversive Thirdness, and the erstwhile hegemonic discourse of Thirdness suffered the consequences. Persistent women, makers of alternative signs, gave vent to their signs of vagueness, brought them to their most supreme expression, and they were eventually interpreted by their signs in terms of generalities, and found the interpretation to be the alternative that demanded the most serious attention. Signs from the overdetermined sphere took their place between the otherwise excluded middle between existent dichotomies of an intransigent polity.

The 'Mothers and Grandmothers of May Square' and related movements in Latin America bear perhaps the most striking illustration in the world of what Roberto DaMatta (1991) calls 'relational society', where the whole follows a logic the parts can choose to ignore. The "and" of 'Both A and Not-A' fuses and confuses the mansions and the shanties, the powerful and the weak, the dominant and the subaltern. DaMatta's concept of 'relational society' is perhaps no more strikingly exemplified than in Latin American mestizaje (racial and ethnic mixture). Mestizaje entails nonlinear interrelations. The mestizo of today, especially in countries like Mexico, Colombia, Peru, Venezuela, Northeastern Brazil, and the Caribbean, is no simple mix of European and Amerindian or African and European or Amerindian and African. The mix is virtually randomly variegated. ${ }^{11}$ Moreover, mestizaje is not merely a racial fact, but in addition, it is the incorporation of the Latin Americans' way of life, their very existence, the becomingness of their being, the beingness of their becoming. Mestizaje is more than an abstraction, it speaks, it perceives, conceives, narrates, becomes at once an actor and a spectator on the stage of everyday living. I we are to take some anthropolisists at their word, mestizaje also embodies an inner need to exercise control. Eric Wolf writes of the mestizo male as "power seeker" par excellence. The struggle in which he has been historically engaged was more than a means:

${ }^{11}$ Magnus Mörner (1967) provides one of the best general studies of race mixture in colonial Latin America (see also Graham 1990). 
[A]s a validation of self and of one's station in society, it became an end in itself. To the mestizo, the capacity to exercise power is ultimately sexual in character: a man succeeds because he is truly male (macho), possessed of sexual potency. While the Indian strives neither to control nor to exploit other men and women, the mestizo reaches for power over women as over men. As the urge for personal vindication through power is continuous and limitless, so the mestizo possesses "a limitless sexual deficit" which feeds merely upon past conquests. While the Indian man and the Indian woman achieve a measure of balance in their relationship, the mestizo male requires absolute ascendance over women. Thus even familial and personal relationships become battlegrounds of emotion, subject to defeat and to victory. (Wolf 1959: 240) ${ }^{12}$

Mestizaje entails a different socio-politico-economic and cultural sensibility. In tales from the U. S. by way of James Fenimore Cooper, Mark Twain and others we have a pretty dire image of the AfroAmericans, the Amerindians and the mestizos in the U. S. Harvard professor and scientist Louis Agassiz once painted a picture of the non-European ethnic groups and the mestizos of Latin America as physically and morally degraded people. The passing of time has unfortunately done little to temper the North American prejudice toward the mestizo. This is not surprising, given one of the basic differences between Anglo American and Latin American policies on territorial expansion. The Anglo American policy was fundamentally one of exclusion. It fixed limits beyond which the Amerindian should not venture; in fact, the native was looked upon as an encumbrance and should be cleared off, like the forests, the buffalo, and the wolves. The Latin American policy, in contrast, was chiefly one of inclusion - though, as one might expect, there are plenty of exceptions to the rule. Consequently, even though the mestizo's place in society in the Latin American colonies left plenty to be desired, he fared considerably better there than in the U. S. Quite ironically, given the distinction between exclusionary and inclusionary practices, during the nineteenth century, travelers, businessmen, and diplomats from the U. S. to Latin America generally enthused over the cultured oligarchy in Latin America. On the other hand, they had few kind words for the mestizo class, which was often assumed to be no more than a bastard

${ }^{12}$ Wolf is admittedly overgeneralizing and exaggerating. But a grain of credence must be allowed him, for he does reveal some of the chief characteristics of the mestizo, though exceptions abound and as the mestizo becomes more numerous his characteristics become more heterogenous and less homogenous. Moreover, the mestiza must also be given due consideration, and she has been since the time of Wolf's study. 
people (Pike 1992: 144-151). In the 1930s historian Herbert Eugene Bolton (1939: 98) saw the Spanish-Anglo borderlands as a "meeting place and fusing place of two streams of European civilization, one coming from the south, the other from the north". Had Bolton been more keen on actual empirical studies of border cultures, however, he would have realized that long before development of his "borderlands" thesis, North American racism had taken its toll.

Nevertheless, I repeat, mestizaje entails an entirely different sociopolitico-economic and cultural sensibility, and until and unless that fact is acknowledged by peoples of non-mestizo cultures, whether inside our outside Latin America, there will be little hope of understanding this hybrid mix, let alone of coping with it and merging with it. This most complex hybrid mix is an openness to institutions and realities of everyday living, to the subjectivity of the social actors and the multiplicity of loyalties, to the relations of patronage, paternalism, and so on, that operate simultaneously in Latin America. It is a constant weaving, unraveling, and re-weaving of intricate ties and relations and encounters and elbow rubbing. There are continuities of relations broken by frequent discontinuities, and reconciliations and renew continuities (García Canclini 1995).

In Latin America cultures, uncertainty is the tenuous rule, vagueness finds its way into every nook and cranny, and everything is always already in the incompletable process of becoming in the sense of semiosic process, in spite of the persistent hard-line view of Latin America that remains obstinately mired in bivalent logic, in a Manichean mind-set.

\section{References}

Agassi, Joseph 1975. Science in Flux. Dordrecht-Holland: D. Reidel.

Agosín, Marjorie 1992. Circles of Madness: Mothers of the Plaza de Mayo. Trans.

Kostopulos-Cooperman, C. San Francisco: White Pine Press.

Bateson, Gregory 1972. Steps to an Ecology of Mind. New York: Chandler.

Bolton, Herbert Eugene 1939. Wider Horizons of American History. New York:

D. Appleton-Century.

Bourdieu, Pierre 1990. The Logic of Practice. Cambridge: Polity.

Bourdieu, Pierre; Passeron. J.-C. 1977. Reproduction in Education, Society and Culture. London: Sage.

Bouvard, Marguerite Guzmán 1994. Revolutionizing Motherhood: The Mothers of the Plaza de Mayo. Wilmington: Scholarly Resources. 
Brown, James Robert 1991. The Laboratory of the Mind: Thought Experiments in the Natural Sciences. New York: Routledge.

Certeau, Michel de 1984. The Practice of Everyday Life. Berkeley: University of California Press.

DaMatta, Robert 1991. Carnivals, Rogues, and Heroes: An Interpretation of the Brazilian Dilemma. Trans. Drury, J. Notre Dame: University of Notre Dame Press.

Fiske, John 1989. Reading the Popular. New York: Routledge.

Galileo Galilei 1967. Dialogue Concerning the Two Chief World Systems. Trans. Drake, S. 2nd ed. Berkeley: University of California Press.

García Canclini, Néstor 1984. Gramsci con Bourdieu. Nueva Sociedad 71: 45-62.

- 1995. Hybrid Cultures: Strategies for Entering and Leaving Modernity. Trans. Chiappari, C. L.; López, S. L. Minneapolis: University of Minnesota Press.

Graham, Richard (ed.) 1990. The Idea of Race in Latin America, 1870-1940. Austin: University of Texas Press.

Hacking, Ian 1985. Styles of scientific reasoning. In: Rajchman, J.; West, C. (eds), Post-Analytic Philosophy. New York: Columbia University Press, 145-165.

Hall, Stuart 1981. Notes on deconstructing "the popular". In: Samuel, R. (ed.), People's History and Socialist Theory. London: Routledge and Kegan Paul, 227-240.

Hartshorne, Charles 1970. Creative Synthesis and Philosophic Method. LaSalle: Open Court.

Hempel, Carl 1945. Studies in the logic of confirmation. Mind 54: 1-26; 97-121.

Hesse, Mary 1980. Revolutions and Reconstructions in the Philosophy of Science. Bloomington: Indiana University Press.

Lotman, Jurij 1977a. The Structure of the Artistic Text. Trans. Vroon, R. (Michigan Slavic Contributions 7.) Ann Arbor: University of Michigan.

- 1977b. Myth - name - culture. In: Lucid, D. (ed.), Soviet Semiotics. Baltimore: Johns Hopkins University Press, 233-252.

- 1990. Universe of the Mind: A Semiotic Theory of Culture. Trans. Shukman, Ann. Bloomington: Indiana University Press.

Lotman, Ju. M.; Uspenskij, B. A. 1984. The Semiotics of Russian Culture. (Michigan Slavic Contributions 11.) Ann Arbor: University of Michigan.

Lugones, María 1994. Purity, impurity, and separation. Signs 19(2): 458-477.

Mallon, Florencia E. 1995. Peasant and Nation: The Making of Postcolonial Mexico and Peru. Berkeley: University of California Press.

Merrell, Floyd 1995a. Semiosis in the Postmodern Age. West Lafayette: Purdue University Press.

- 1995b. Peirce's Semiotics Now: A Primer. Toronto: Canadian Scholars' Press.

- 1996. Signs Grow: Semiosis and Life Processes. Toronto: University of Toronto Press.

- 1997. Peirce, Signs, Meaning. Toronto: University of Toronto Press.

- 2000a. Change through Signs of Body, Mind, and Language. Chicago: Waveland.

- 2000b. Signs, Science, Self-Subsuming Art(ifacts). Dresden: Thelem.

- 2000c. Tasking Textuality. Peter Lang. 


\section{Floyd Merrell}

Mörner, Magnus 1967. Race Mixture in the History of Latin America. Boston: Little, Brown.

Nakhimovsky, Alexander D.; Nakhimovsky, Alice Stone (eds.) 1985. The Semiotics of Russian Cultural History. Ithaca: Cornell University Press.

Peirce, Charles Sanders 1931-35. Collected Papers of Charles Sanders Peirce. Hartshorne, C.; Weiss, P. (eds.), vols. 1-6. Cambridge: Harvard University Press. [Reference to Peirce's papers will be designated CP]

- 1958. Collected Papers of Charles Sanders Peirce. Burke, A. W. (ed.), vols. 7-8. Cambridge: Harvard University Press.

Pike, Fredrick B. 1992. The United States and Latin America: Myths and Stereotypes of Civilization and Nature. Austin: University of Texas Press.

Sebeok, Thomas A. 1991. In what sense is language a "primary modeling system"? In: Anderson, Myrdene; Merrell, Floyd (eds.), On Semiotic Modeling. Berlin: Mouton de Gruyter, 327-339.

Shukman, Ann 1977. Literature and Semiotics: A Study of the Writings of Yu. M. Lotman. Amsterdam: North-Holland.

Spencer-Brown, G. 1972. Laws of Form. New York: E. P. Dutton.

Wolf, Eric 1959. Sons of the Shaking Earth. Chicago: University of Chicago Press.

\section{Семиосфера Лотмана, категории Пирса и жизненные формы культуры}

В статье семиотическое пространство Лотмана соотносится с категориями Пирса. Отдельные формы манифестации семиотического пространства культуры в семиосфере могут, в зависимости от контекста культуры, описываться как противоречивые и/или неполные. Противоречивость и неполнота соотносятся по своему характеру соответственно с сверхдетерминированностью и недодетерминированностью, которые, в свою очередь, могут описываться соответственно посредством неопределенности и общепризнанности. Первая из них по своему характеру связана с категорией Первичности, вторая с категорией Третичности. Роль Вторичности - выделить возможности Первичности: определить это и то, тут и там, теперь и тогда и, исходя из этого, определить и все остальные различия. С точки зрения семиотического пространства культуры Вторичность делает возможным возникновение гегемонии, отношений доминирования и подчинения, суперординации и субординации. Интергтретируя Вторичность таким образом, мы можем сверхдетерминированность и недодетерминированность характеризовать соответственно как гомогеничность и гетерогеничность. Исходя из этих теоретических предпосылок рассматриваются многие существенные моменты в культурах Латинской Америки. 


\title{
Lotmani semiosfäär, Peirce'i kategooriad ja kultuuri eluvormid
}

\begin{abstract}
Artiklis seostatakse Lotmani semiootiline ruum Peirce'i kategooriatega. Kultuuri semiootilise ruumi teatud avaldumisvormid semiosfääris on, kultuurikontekstist sõltuvalt, kirjeldatavad kui vastuolulised ja/või mittetäielikud. Vastuolulisus ja mittetäielikkus sarnanevad oma iseloomult vastavalt üledetermineeritusele ja aladetermineeritusele, need on omakorda kirjeldatavad vastavalt ebamäärasuse ja üldkehtivuse kaudu. Esimene neist on oma iseloomult seotud Esmasuse, teine aga Kolmasuse kategooriaga. Teisesuse roll on eristada Esmasuse võimalikkused: määratleda see ja too, siin ja seal, nüüd ja siis ning kõik ülejäänud nendest järelduvad eristused. Kultuuri semiootilise ruumi seisukohast teeb Teisesus seega võimalikuks hegemoonia tekke, domineerimis- ja alluvussuhted, superordinatsiooni ja subordinatsiooni. Teisesust niimoodi tõlgendades saame me üledetermineeritust ja aladetermineeritust käsitleda vastavalt kui homogeensust ja heterogeensust. Nendest teoreetilistest eeldustest lähtudes vaadeldakse seejärel mitmeid olulisi momente Ladina-Ameerika kultuurides.
\end{abstract}

